\title{
Combination of C21 and ARBs with rhACE2 as a therapeutic protocol: A new promising approach for treating ARDS in patients with coronavirus infection
}

\author{
Marzieh Soheili ${ }^{1,2}$, Kaveh Haji-allahverdipoor ${ }^{3,4}$, Mohamad Bagher Khadem-erfan ${ }^{1}$, Babak Baban $^{5}$, Bahram Nikkhoo ${ }^{1,6}$, \\ Anwar Eliasi ${ }^{7}$, Sherko Nasseri*1 (D)
}

Received: 2 Apr 2020

Published: 14 Sep 2020

\begin{abstract}
Background: Coronavirus disease 2019 (COVID-19) is caused by a new severe acute respiratory syndrome Coronavirus. COVID19 patients are at risk for acute respiratory distress syndrome and death from respiratory failure.

Methods: In this study the complete genome of the SARS-CoV-2 reference sequence, geologically isolated types, and Coronavirus related to human diseases were compared by the Molecular Phylogenetic Maximum Likelihood method. The secondary and tertiary structures of the main protease of SARS-CoV were defined as the most similar viruses to SARS-CoV-2, aligned with chimera software. Therefore, considering ineffective antiviral medications used for SARS-CoV and the importance of preventing acute respiratory distress syndrome as the main cause of mortality, 2 strategies were adopted to acquire the most effective drug combination.

Results: The results of phylogenic analysis showed that SARS-CoV is the most similar virus to SARS-CoV-2. The secondary structure and superimposing of tertiary structure did not show a significant difference between SARS and SARS-CoV-2 3C-like main protease and the root means square deviation between $\mathrm{C} \alpha$ atoms did not support the difference between the 2 protein structures. Thus, these 2 mechanisms were fostered in accordance with the correlation between acute respiratory distress syndrome-related Coronavirus, angiotensin-converting enzyme 2 on one side and the possible treatments for reducing the respiratory side effects on the other. The analysis of renin-angiotensin system as well as the tested drugs applied to acute respiratory distress syndrome cases, indicated that angiotensin II receptor blockers, angiotensin-converting enzyme inhibitors, and C21 as nonpeptide agonist might possess a promising modality of treatment for acute respiratory distress syndrome. Furthermore, implementing recombinant human ACE2 as a competitive receptor might be an effective way to trap and chelate the SARS-CoV-2 particles.

Conclusion: The data suggest that combination therapy of angiotensin II receptor blockers and C21 could be a potential pharmacologic regimen to control and reduce acute respiratory distress syndrome. Moreover, rhACE2 can be recommended as an effective protective antiviral therapy in the treatment of COVID-19 and its complications.
\end{abstract}

Keywords: Acute respiratory distress syndrome, SARS-Associated Coronavirus, Renin-Angiotensin system, SARS-CoV-2

Conflicts of Interest: None declared

Funding: None

*This work has been published under CC BY-NC-SA 1.0 license.

Copyright $₫$ Iran University of Medical Sciences

Cite this article as: Soheili M, Haji-allahverdipoor K, Khadem-erfan MB, Baban B, Nikkhoo B, Eliasi A, Nasseri Sh. Combination of C21 and ARBs with rhACE2 as a therapeutic protocol: A new promising approach for treating ARDS in patients with coronavirus infection. Med J Islam Repub Iran. 2020 (14 Sep);34:120. https://doi.org/10.47176/mjiri.34.120

Corresponding author: Dr Sherko Nasseri, sherko.nasseri@muk.ac.ir

1. Cellular and Molecular Research Center, Research Institute for Health Development, Kurdistan University of Medical Sciences, Sanandaj, Iran

2. Faculty of Medicine, Kermanshah University of Medical Sciences, Kermanshah, Iran

3. Department of Biotechnology and Plant Breeding, Faculty of Agriculture, Tarbiat Modares University, Tehran, Iran

4. Young Researchers and Elites Club, Science and Research Branch, Islamic Azad University, Tehran, Iran

5. Department of Oral Biology and Diagnostic Sciences, DCG, Augusta University, Augusta GA, USA

6. Department of Pathology, Faculty of Medicine, Kurdistan University of Medical Sciences, Sanandaj, Iran

. Department of Surgery, Faculty of Medicine, Kurdistan University of Medical Sciences, Sanandaj, Iran $\uparrow$ What is "already known" in this topic:

COVID-19 has become an epidemic and eventually a global pandemic burden worldwide. COVID-19 patients are at risk for acute respiratory distress syndrome and death from respiratory failure. The Coronavirus antiviral treatment had no significant therapeutic or preventive effect and there is no effective treatment strategy to prevent death from COVID-19.

\section{$\rightarrow$ What this article adds:}

This study suggests the combination of $\mathrm{C} 21$ and ARBs as an applicable effective therapeutic protocol. Also, rhACE2 acts as a competing molecule for the SARS-CoV-2 receptor, and by binding to SARS-CoV-2, it reduces the binding of the virus to its receptor at the tissue level and can be potentially added to the current treatment protocol as an effective method. 


\section{Introduction}

The Coronavirus family includes pathogens of many animal species and humans. There are 6 different $\mathrm{CoV}$ strains in humans: HCoV-229E (229E), HCoVOC43(OC43), severe acute respiratory synd rome Coronavirus (SARS-CoV), HCoV NL63 (NL63), HCoVHKU1 (HKU1), and Middle East respiratory syndrome Coronavirus (MERS-CoV) (1). Coronavirus-19 (SARSCoV-2) is a novel virus found in Wuhan, China, in December 2019 and can cause respiratory signs and symptoms similar to SARS and MERS (2). It is an enveloped and single-strained ribonucleic acid having 9-12 nm-long surface spikes. The $\mathrm{S}$ protein is one of the 4 major proteins on the envelope binding to the angiotensinconverting enzyme2 (ACE2) receptor for entering the host cell $(3,4)$. It can be transmitted through human-to-human contacts mainly by respiratory droplets (5). The median time to show the symptoms is 9 days (6). SARS and MERS were epidemics in 2003 and 2014, respectively (7, $8)$. The evaluation of the SARS-CoV-2 outbreak shows that the virus is more prevalent in men $(73 \%)$ and has a case fatality ratio (CFR) of $2 \%$. MERS is also common in men $(66.6 \%)$. Nonetheless, the CFR is much higher than SARS-CoV-2 (35\%). Women represented a higher prevalence $(55.7 \%)$ of SARS with a CFR between $13.2 \%$ $22.3 \%(2)$.

There is a spectrum of symptoms, mainly nonspecific, from asymptomatic to death (9). Fever, cough, myalgia, fatigue, nausea, diarrhea, and headache are the probable symptoms of $\mathrm{CoV}(10,11)$. The onset may present with rapid progression to shock or acute respiratory distress syndrome (ARDS), acute kidney injury, or acute cardiac injury $(5,12)$. In blood test assay, patients might have lower blood cell counts (lymphopenia, thrombocytopenia, increased C-reactive protein level, erythrocyte sedimentation rate, lactate dehydrogenase, creatinine, and prolonged prothrombin time) $(10,12-14)$. Chest radiography cannot be a useful radiological examination in the early stages of infection (15). chest CT provides a fast, convenient, and effective method for detection of COVID-19 (16). Indeed, full genome sequencing as well as PCR-based diagnosis of the SARS-CoV-2 genome in bronchoalveolar secretion is necessary to confirm the presence of virus (17).The SARS-CoV-2 virus contains a 3C-like proteinase enzyme that breaks down a large viral protein called polypropine ORF1ab into 2 locations, including the TSAVLQSGFRK-NH2 and SGVTFQ-GKFKK sequence regions, breaking it down into smaller enzymatic proteins.

The Coronavirus antiviral treatments are as follow:

1. Coronavirus protease inhibitors

1.1. Chymotrypsin-like (3C-like) inhibitors: cinanserin, flavonoids

1.2. Papain-like protease (PLP) inhibitors: diarylheptanoids

2. Spike (S) protein-angiotensin-converting enzyme 2 (ACE2) blockers or S protein inhibitors: human monoclonal antibody $(\mathrm{mAb})$, chloroquine, emodin, promazine, nicotianamine

3. Antiviral treatments: ribavirin, lopinavir
(LPV)/ritonavir (RTV) (Kaletra), remdesivir, nelfinavir, arbidol, nitric oxide

COVID-19 has become an epidemic and eventually a global pandemic burden by involving more than 100 countries (18). Approximately $40 \%$ of the cases are active (currently infected patients) and about 60\% closed cases (cases which had an outcome), with approximately 94\% recovered and $6 \%$ dead (19). The total estimated death is about $3.5 \%$, while the mortality rate was $10 \%$ for SARS and 34\% for MERS (20). At the onset of the Coronavirus epidemic, mortality increased from $2 \%$ to $3.4 \%$ and then decreased to about $1 \%$, which is related to the severity of ARDS in COVID-19(21), and ineffective therapies that mainly focused on antiretroviral therapy. In this study we evaluated the genomic and protein sequences of humanassociated Coronavirus that cause disease in a comparative fashion. Comparison was done based on homology to find an effective antiviral treatment pattern. Further, we assessed the potential for adopting a more comprehensive therapeutic modality by adding vasodilatation and antiproliferation therapies to the current antiviral treatment in patients with ARDS-associated Coronavirus.

\section{Methods}

\section{Data acquisition and phylogenic tree draw}

The complete genomes of the first main Wuhan $\mathrm{nCoV}$ 19 and 43 isolated types of novel SARS-CoV-2 with identical geology were retrieved the novel severe acute respiratory syndrome Coronavirus 2 genome data hub. Also, 12 complete genomes from alpha and beta Coronavirus were derived from the US National Library of Medicine, NCBI database. All the retrieved sequences selected from alpha and beta Coronavirus that cause important mild and severe diseases in humans were common between humans and vertebrates (Table 1). The Mega7 software was used for the generation of the phylogenetic tree (22). The Maximum Likelihood method based on the Tamura-Nei model with 1000 bootstrap was selected for phylogenetic analysis (23). Phylogenetic trees based on virus genomes and deduced amino acid sequences of ORF were constructed by Maximum Likelihood.

\section{$2 D$ and $3 D$ structure alignment}

The model structures of the 3C-like main protease of the SARS-CoV-2 (6LU7) and the SARS-CoV (1q2w), retrieved by PDB, were taken and analyzed by treating PDB primary structure by filling in missing residues. Also, the alignment of protein sequences, the secondary and tertiary structure between SARS-CoV and SARS-CoV-2 C-like main protease, was done by chimera software. RMSD (root mean square deviation) between $\mathrm{C} \alpha$ atoms was calculated by chimera software and was 0.979 .

\section{Search strategy}

To retrieve relevant studies, we aimed to choose an appropriate search strategy. We implemented a comprehen- 
Table 1. The members of the genus of alpha and beta coronavirus that has greater clinical importance concerning humans are listed based on a host, receptors, pathogenic symptoms, and mortality were shown. No data found in the line areas

\begin{tabular}{|c|c|c|c|c|c|c|c|}
\hline Virus name & $\begin{array}{c}\text { Accession } \\
\text { Number refer- } \\
\text { ence }\end{array}$ & Source information & $\begin{array}{l}\text { Proteins } \\
\text { encoded }\end{array}$ & Host & receptor & Clinical feature & $\begin{array}{c}\text { Outbreak } \\
\text { mortality } \\
\text { /year }\end{array}$ \\
\hline $\begin{array}{l}\text { Human Coronavirus } \\
\text { HKU1 }\end{array}$ & NC_006577 & Isolate: HKU1 & 8 & Human & $\begin{array}{l}\text { O-acetylated sialic } \\
\text { a } 1 \text { acid (52) }\end{array}$ & $\begin{array}{l}\text { Febrile convul- } \\
\text { sion (53) }\end{array}$ & $\begin{array}{c}\text { N/A (54)/ } \\
\text { November } \\
2007 \text { to } \\
\text { March } 2008 \\
\quad(53)\end{array}$ \\
\hline $\begin{array}{l}\text { Human coronavirus } \\
\text { NL63 }\end{array}$ & NC_005831 & $\begin{array}{l}\text { Strain: Amster- } \\
\text { dam I }\end{array}$ & 6 & Human & ACE2 (55) & Croup (53) & N/A (54) \\
\hline $\begin{array}{l}\text { Betacoronavirus } \\
\text { England } 1\end{array}$ & NC_038294 & $\begin{array}{c}\text { Strain: England } \\
\text { 1; iso- } \\
\text { late:H123990006 }\end{array}$ & 10 & $\begin{array}{l}\text { Human, } \\
\text { Vertebrates }\end{array}$ & --------- & --------- & ------------- \\
\hline Bovine coronavirus & NC_003045 & $\begin{array}{c}\text { Isolate: } \mathrm{BCoV-} \\
\text { ENT }\end{array}$ & 12 & $\begin{array}{l}\text { Human, } \\
\text { Vertebrates }\end{array}$ & $\begin{array}{l}\mathrm{N} \text {-acetyl-9-O- } \\
\text { acetylneuraminic } \\
(56)\end{array}$ & Diarrhea (57) & $\begin{array}{l}\text {-------/ Win- } \\
\text { ter 2006 (58) }\end{array}$ \\
\hline $\begin{array}{l}\text { Camel alphacorona- } \\
\text { virus }\end{array}$ & NC_028752 & $\begin{array}{l}\text { Isolate: cam- } \\
\text { el/Riyadh/Ry141/ } \\
2015\end{array}$ & 7 & $\begin{array}{l}\text { Human, } \\
\text { Vertebrates }\end{array}$ & ------ & $\begin{array}{l}\text { Asymptomatic } \\
\text { (59) }\end{array}$ & ------ \\
\hline $\begin{array}{l}\text { Human coronavirus } \\
229 \mathrm{E}\end{array}$ & NC_002645 & Strain: $229 \mathrm{E}$ & 8 & $\begin{array}{l}\text { Human, } \\
\text { Vertebrates }\end{array}$ & $\begin{array}{l}\text { Human aminopep- } \\
\text { tiddase } N(60)\end{array}$ & $\begin{array}{l}\text { Mild respirato- } \\
\text { ry symp- } \\
\text { toms(mostly } \\
\text { common in } \\
\text { immunocom- } \\
\text { promised indi- } \\
\text { viduals (57) }\end{array}$ & $\begin{array}{l}\text { N/A (54) / } \\
\text { Winter } 2008 \\
\quad(53)\end{array}$ \\
\hline $\begin{array}{l}\text { Human coronavirus } \\
\text { OC43 }\end{array}$ & NC_006213 & $\begin{array}{l}\text { Strain: ATCC } \\
\text { VR-759; sero- } \\
\text { type:OC43 }\end{array}$ & 8 & $\begin{array}{l}\text { Human, } \\
\text { Vertebrates }\end{array}$ & $\begin{array}{l}\text { HLA class I anti- } \\
\text { gen }(61)\end{array}$ & $\begin{array}{c}\text { Necrotizing } \\
\text { entrocolitis and } \\
\text { gastroenteritis } \\
\text { (62) }\end{array}$ & $\begin{array}{l}\text { N/A (54) / } \\
\text { November } \\
2008 \text { to } \\
\text { January } \\
2009(53) / \\
\text { Summer } \\
2003(64)\end{array}$ \\
\hline $\begin{array}{l}\text { Infectious bronchitis } \\
\text { virus }\end{array}$ & NC_001451 & Strain: Beaudette & 10 & $\begin{array}{l}\text { Human, } \\
\text { Vertebrates }\end{array}$ & Sialic acid (64) & $\begin{array}{l}\text { Severe respira- } \\
\text { tory disease, } \\
\text { nephritis }(57), \\
\text { reproductive } \\
\text { disorders }(65)\end{array}$ & $\begin{array}{c}20-30 \% \\
(65)-------\end{array}$ \\
\hline $\begin{array}{l}\text { Middle East respira- } \\
\text { tory syndrome- } \\
\text { related coronavirus }\end{array}$ & NC_019843 & $\begin{array}{l}\text { Strain: } \mathrm{HCoV}- \\
\text { EMC }\end{array}$ & 11 & $\begin{array}{l}\text { Human, } \\
\text { Vertebrates }\end{array}$ & $\begin{array}{l}\text { dipeptidyl pepti- } \\
\text { dase 4(DPP4) (66) }\end{array}$ & $\begin{array}{l}\text { Severe acute } \\
\text { respiratory } \\
\text { syndrome (57) }\end{array}$ & $\begin{array}{l}37 \%(57) / \\
2012 \text { and } \\
2015\end{array}$ \\
\hline $\begin{array}{l}\text { Severe acute respira- } \\
\text { tory syndrome coro- } \\
\text { navirus } 2\end{array}$ & NC_045512 & Wuhan-Hu-1 & 12 & $\begin{array}{l}\text { Human, } \\
\text { Vertebrates }\end{array}$ & ACE2 (67) & $\begin{array}{l}\text { Severe and } \\
\text { Mild respirato- } \\
\text { ry disease (57) }\end{array}$ & $\begin{array}{c}2-3.4 \%(68) \\
\quad / 2019\end{array}$ \\
\hline $\begin{array}{l}\text { Severe acute respira- } \\
\text { tory syndrome- } \\
\text { related coronavirus }\end{array}$ & NC_004718 & Isolate: Tor2 & 14 & $\begin{array}{l}\text { Human, } \\
\text { Vertebrates }\end{array}$ & ACE2 (69) & $\begin{array}{l}\text { Severe respira- } \\
\text { tory disease } \\
(70)\end{array}$ & $\begin{array}{l}9.5 \%(70) / \\
2003\end{array}$ \\
\hline Turkey coronavirus & NC_010800 & Isolate: MG10 & 11 & $\begin{array}{l}\text { Human, } \\
\text { Vertebrates }\end{array}$ & ---------- & $\begin{array}{l}\text { Depression, } \\
\text { loss of appetite, } \\
\text { weight loss, } \\
\text { diarrhea, hem- } \\
\text { orrhage in the } \\
\text { jejunum, ileum, } \\
\text { cecum ( } 71)\end{array}$ & $\begin{array}{l}\text { Very low } \\
\text { (71) }\end{array}$ \\
\hline
\end{tabular}

sive search strategy in PubMed (including Medline), Embase, and Scopus. Our search was mostly focused on the correlation between Coronavirus and ARDS, ACE2 as the main receptor of the virus, and the possible treatments to improve the therapeutic algorithm for reducing the respiratory side effects of this infection. We followed the 3 routes below:

1. The rout correlated with the drugs reduce viral parti- 
cle binding to the ACE2

2. The rout related to the medications decrease AT1R.

3. The rout defining the drugs increase AT2R.

About 137 papers were retrieved, of which 33 were selected and evaluated. Any signs, symptoms, or treatments which were not correlated with ARDS-related Coronavirus were excluded. We also included review papers, book chapters, and letters to the editor.

\section{Pharmacophore-based virtual screening}

In this study, 3D structure of the $\mathrm{C} 21$ compound was predicted and minimized using molecular mechanic forcefield "MM+" and quantum mechanic based semiempirical "AM1" method. Pharmacophore modeling and pharmacophore-based virtual screening were done with
Pharmit server (http://pharmit.csb.pitt.edu).

\section{Results}

The phylogenic analysis assessed the complete genome similarity of Wuhan's main reference sequence of SARSCoV-2(NC_045512), other specified geological isolated of SARS-CoV-2, and other alpha and beta Coronaviruses associated with human diseases. The results of the phylogenic analysis and distance analysis (data not shown) showed that the SARS-CoV is the most similar virus to SARS-CoV-2 (Fig. 1). The 3C-like main protease of SARS-CoV-2 and SARS-CoV, which is in the center of attention for antiviral treatment, was analyzed. The final model, alignment of the protein sequence, and the secondary structure and superimposing of tertiary structure did not show a significant difference between SARS and

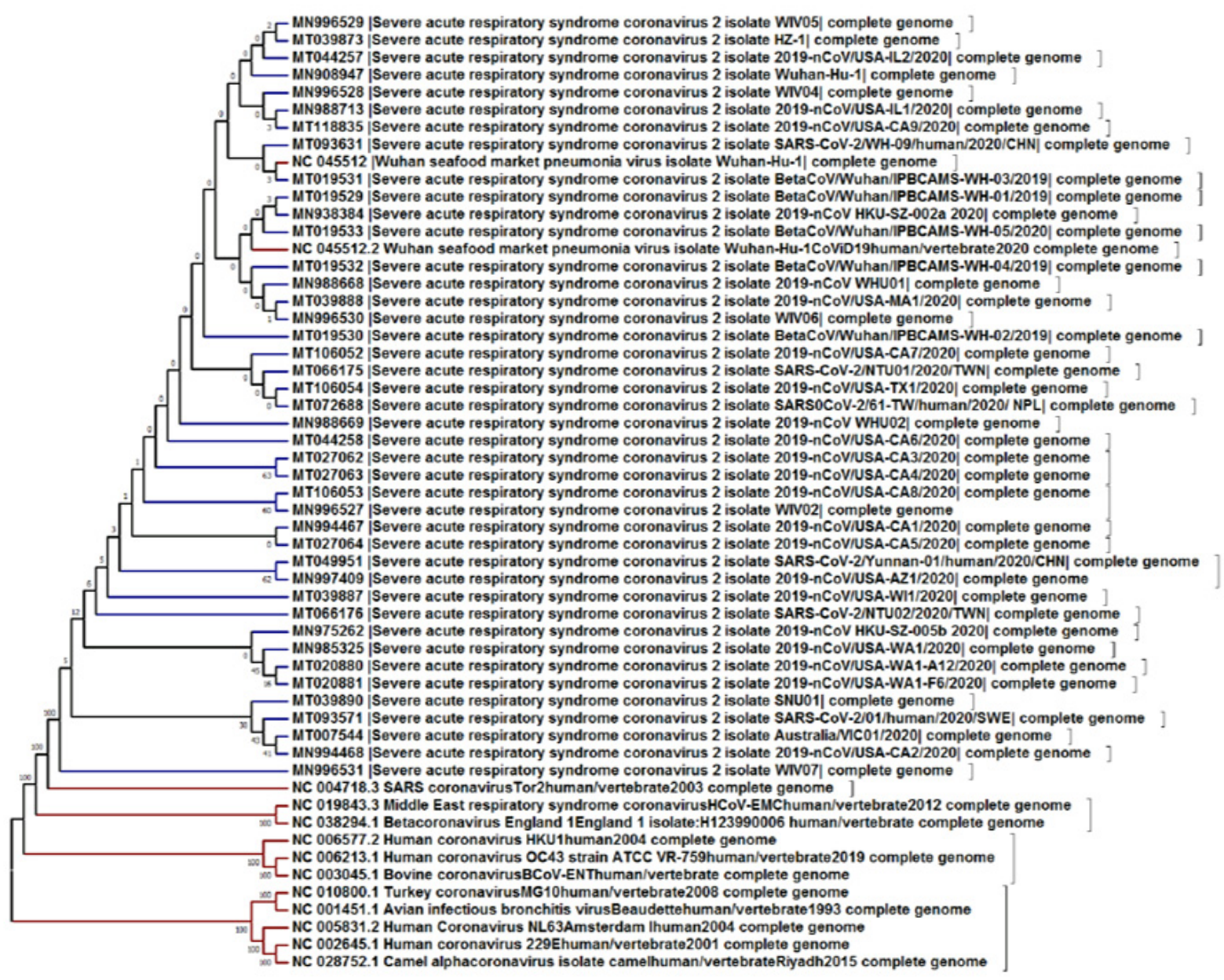

Fig. 1. Molecular Phylogenetic analysis by the Maximum Likelihood method. The evolutionary history was inferred by using the Maximum Likelihood method based on the Tamura-Nei model (55). The tree with the highest log likelihood (-225915.89) is shown. The percentage of trees in which the associated taxa clustered together is shown next to the branches. Initial tree(s) for the heuristic search were obtained automatically by applying Neighbor-Join and BioNJ algorithms to a matrix of pairwise distances estimated using the Maximum Composite Likelihood (MCL) approach and then selecting the topology with superior log likelihood value. The analysis involved 55 nucleotide sequences. Codon positions included were $1 s t+2 n d+3 r d+$ Noncoding. All positions containing gaps and missing data were eliminated. There were a total of 24218 positions in the final dataset. Evolutionary analyses were conducted in MEGA7 (56). 


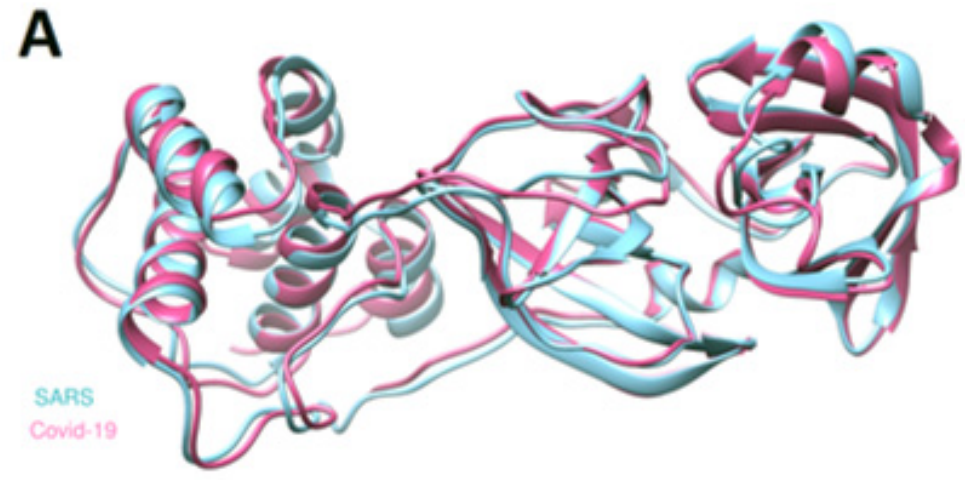

B

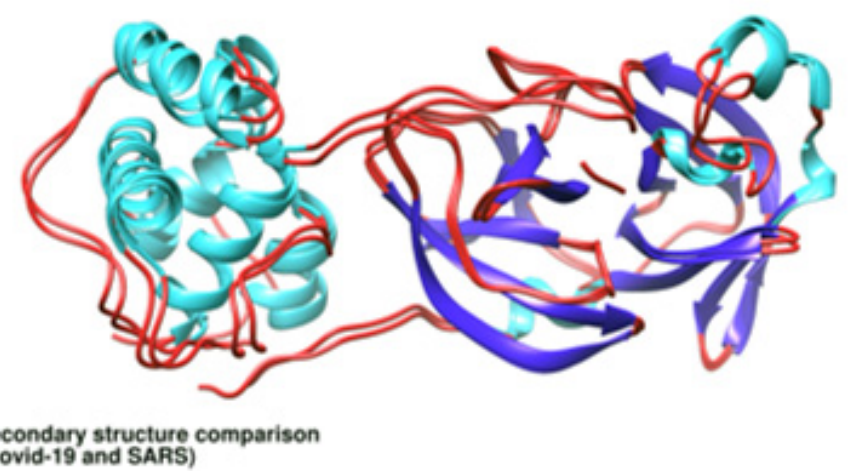

Fig. 2. The comparison of Secondary and tertiary structure of SARS-CoV and SARS-nCoV-19 main protease. A. The superimposition of three-dimensional (3D) structures of SARS-CoV (light blue) and SARS-CoV-2 (purple) main protease showed that the two proteins had the same 3D shape. B. The two-dimensional (2D) structures of SARS-CoV and SARS-CoV-2 main protease aligned by the sheets (light blue) and helix (dark blue). The 2D alignment depicted that these to protein were identical In terms of sheets and helix structures.

SARS-CoV-2 3C-like main protease (Fig. 2). Also, the RMSD (root mean square deviation) between $\mathrm{C} \alpha$ atoms was calculated by chimera software and was 0.979 , which did not support the difference between the 2 protein structures. The results of our evaluations based on the effective drugs of angiotensin 2 receptors in the RAS signaling pathway showed that angiotensin receptor (ARB) II inhibitors, such as losartan, telmisartan and valsartan, could be effective in limiting AT1R activity.

Also, ACE inhibitors, such as captopril, lisinopril, and enalapril, can reduce the production of ANGII and thus prevent AT1R activation. On the other hand, rathinasabapathy et al reported C21 treatment on lung fibrosis induced rats (by bleomycin installation) attenuates lung injury. They recommended further evaluations for applying $\mathrm{C} 21$ as a promising approach for the clinical treatment of idiopathic pulmonary fibrosis (IPF) and Group III PH (24). The search results based on the strategy to reduce viral particle binding to the ACE2 receptor resulted in finding recombinant human ACE2 (rhACE2) as a potential therapeutic approach in the management of emerging lung distress as avian influenza A infections $(25,26)$. Pharmacophore-based virtual screening of databases with millions of compounds (ZINC, PubChem, CHEMBL 25, ChemSpace, MCULE, MolPort, and LabNetwork) could not find any compounds that may match with $\mathrm{C} 21$. Thus, it can be stated that $\mathrm{C} 21$ is a highly selective and specific compound with special structural features having no similar compounds or substitutions (Fig. 3).

\section{Discussion}

High similarity between the complete genomes and subsequently homology of 2 main protease protein structures basically should lead to a similar response to therapeutic targeting, especially for antiprotease therapy. On the other hand, SARS-CoV-2 had a rapid rate of spread and transformation from a local epidemic status in Wuhan to a global pandemic situation that has affected more than 100 countries. Also, there is a great concern about the increase in its fatality rate from $2 \%$ in developed countries to about $3.5 \%$ in developing countries. It can be concluded that antiviral drugs alone could not be effective in reducing 


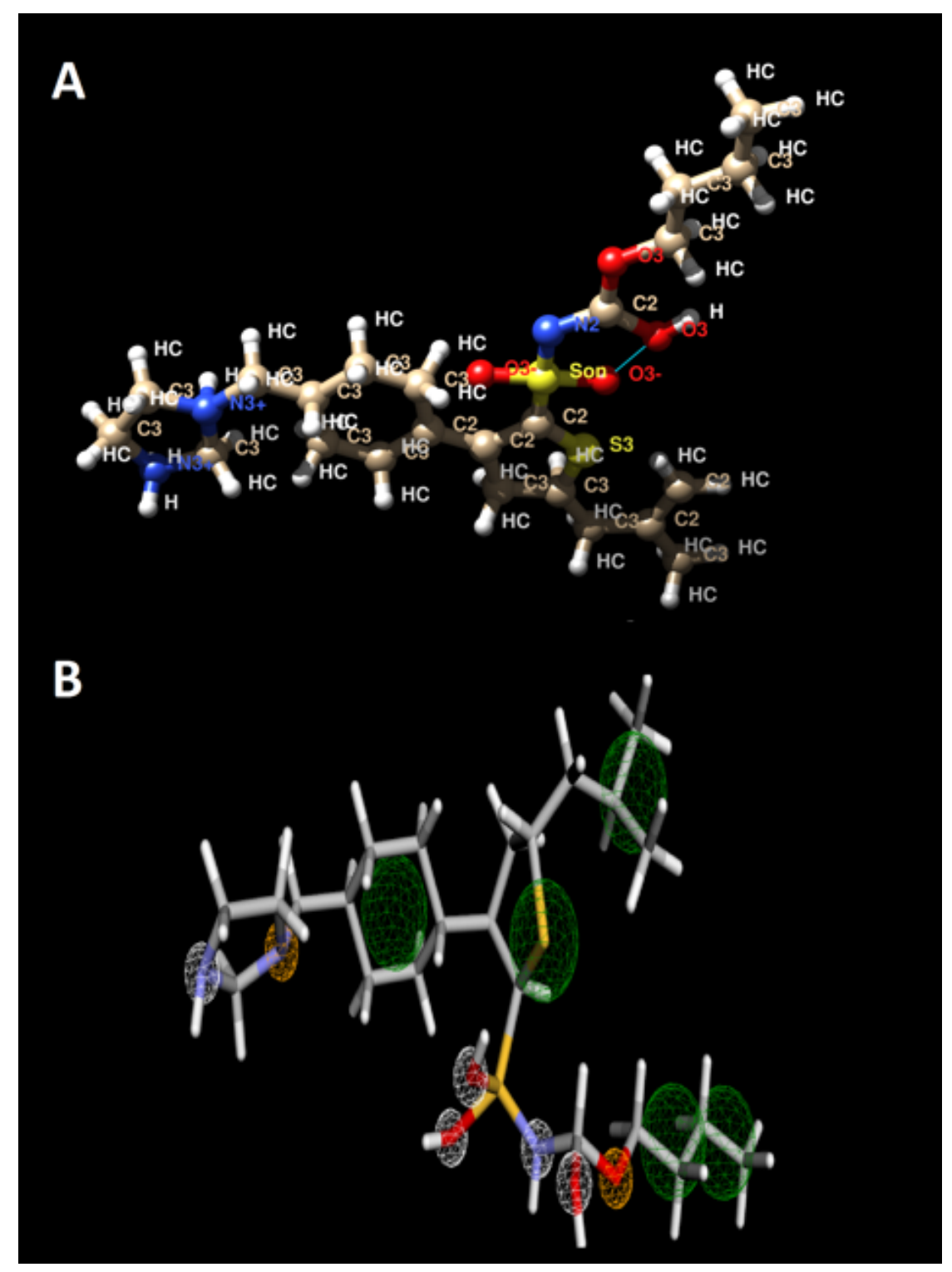

Fig. 3. A. Three-dimensional (3D) structure of the $\mathrm{C} 21$ compound. B. Pharmacophore model of $\mathrm{C} 21$ includes 17 features (white balls indicate hydrogen bond donors, Orange balls indicate hydrogen bond acceptors and Green balls indicate hydrophobic groups)

mortality rates due to viral infection. Thus, reducing the clinical symptoms of critically ill patients suffering from acute respiratory distress syndrome due to novelCoronavirus and diminishing the severity and mortality of patients is an urgent problem to be solved clinically.

ARDS is a distinct condition with characterized clinicopathologic and radiographic findings, involving acute onset and hypoxemia that does not respond to a single effective pharmacological intervention $(27,28)$. ARDS is the most severe form of acute lung distress and is characterized by pulmonary edema, severe hypoxia, and increased inflammatory cells in the lung tissue (29). SARS-CoV-2 is known as the COVID-19 pathogen demonstrating atypical pneumonia with high fever and severe dyspnea (30). From December 31, 2019 up to now, the world has been experiencing an outbreak of SARS-CoV-2. In our assay, we described the correlation of SARS-CoV-2 with ACE2 in the lung to recommend the best treatment for this infection.

The main receptor of the Coronavirus is ACE2, which is the main factor of the renin-angiotensin system (RAS) in pulmonary and cardiovascular disorders $(31,32)$. The normal pathway has been shown in Figure $4 \mathrm{~A}$. As it is presented, ACE accelerates producing ANG II from ANG I. Then, ANG II effects are mediated by its receptor angiotensin receptor 1 (AT1R), which leads to activating vasoconstriction and cell proliferation. On the other hand, ACE2 (expressed in vascular endothelial cells of heart, kidneys, testis, and lung) (33) converts AG II to ANG 1-7 to mediate AT2R receptors for activating vasodilation and apoptosis, which can prevent the proliferation of fibroblasts in the lung (29). One of the important pathways which influences related lung disorders, such as cardiovascular disorders, pulmonary hypertension, pulmonary 
edema, and pulmonary fibrosis, are the diseases related to RAS dysfunction (29). Pulmonary fibrosis is reported as a considerable problem that occurs due to SARS-CoV-2, which is seen in the chest CT scan and is produced through the fibroblasts activated by ANG2 immunereactivation of lung fibroblasts, macrophages and bronchiolar and alveolar epithelium (34). These reactions are seen in the chest CT scan as multiple patchy consolidations and ground-glass opacities (GGO) (35). All these pathologies are because of the involvement of RAS in
SARS pathogenesis. SARS-CoV-2 is downregulated when it binds to its receptor (ACE2). The downregulation of ACE2 expression leads to ARDS through decreasing AT2R and preventing vasodilatation and fibroblast apoptosis (36). Figure $4 \mathrm{~B}$ is representative of this cascade. Kuba et al believe that ACE2 can be applied as a novel drug for controlling ARDS (29). In the case of SARSCoV-2, there is a tentative suggestion that should be considered to treat ARDS in patients with SARS-CoV-2. Since the pathway of AT1R is amplified by SARS-CoV-2,

A

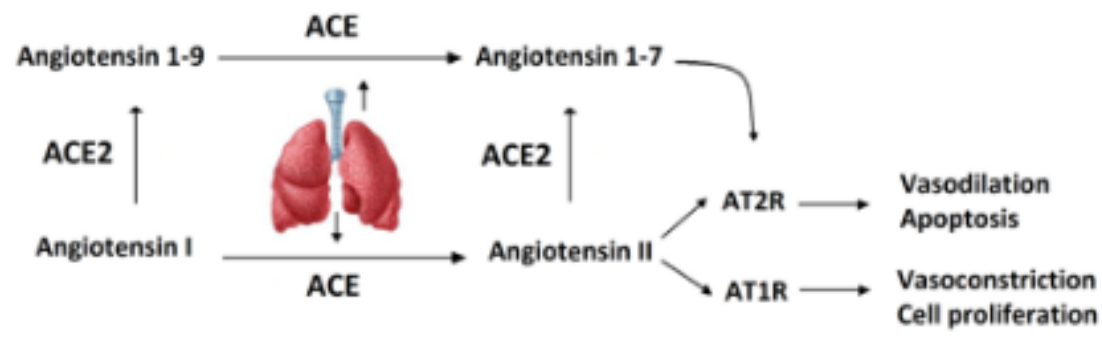

B

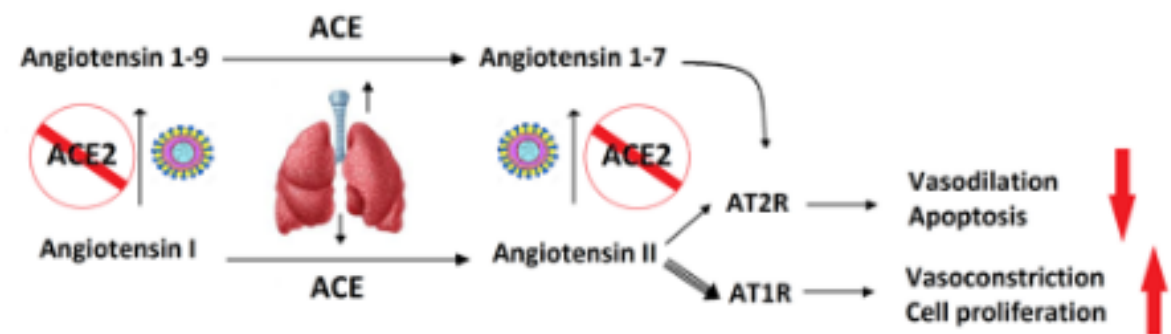

C

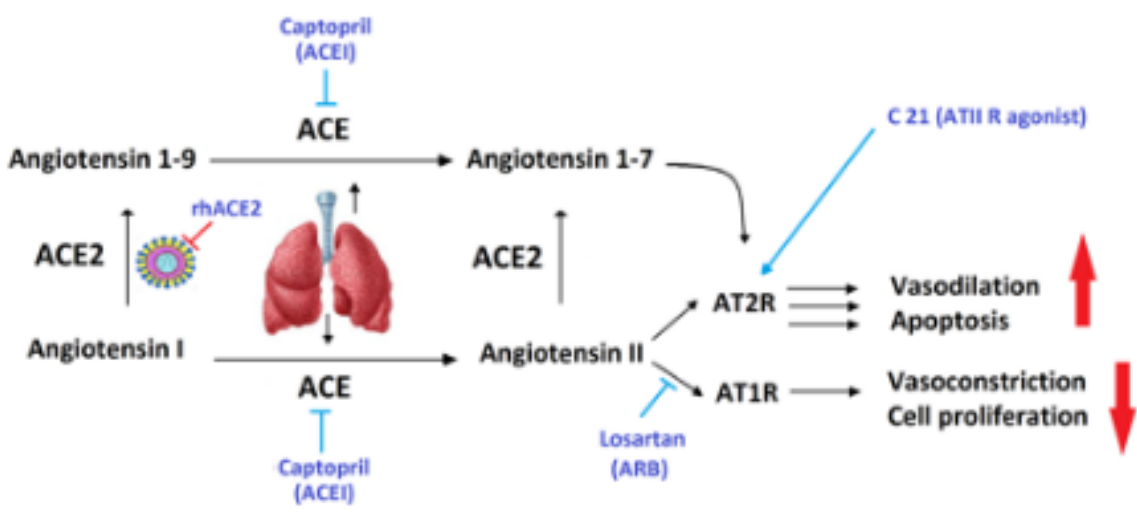

Fig. 4. The Renin-Angiotensin system. A. In physiological conditions, ACE is expressed in the lung. It converts ANG 1 to ANG II. ACE2 causes Angiotensin 1-7 to be produced. Then ACE mediates the effects of ANG 1-7 and AT2R for vasodilatation and cell apoptosis. While ANG2 mediates the pathway of AT1R for a reverse effect which is vasoconstriction and cell proliferation. B. SARS-CoV-2 infection is here. The marked locations are blocked by SARS-Cov-2 which causes the function of AT2R to be decreased leading to vasodilatation as well as cell apoptosis and increased vasoconstriction and cell proliferation. C. The pathways which are blocked by the related drugs. ARBs (Losartan): blocking the production of AT1R. ACEIs (Captopril): blocking the pathway of Angiotensin I to Angiotensin II and Angiotensin 1-9 to Angiotensin 1-7. C21: a substitution for AT2R to compensate for the lack of it during the infection. rhACE2: increasing the amount of ACE2 when it is decreased because of any pathologic situation. 
angiotensin II receptor blockers (ARBs), such as losartan, telmisartan or valsartan, can reduce the intensity of invasion and mortality of SARS-CoV-2 infection (37). Therefore, increasing ACE2 activity and redirecting the RAS pathway in the direction of the ATII R stimulation might be an effective potential therapy for ARDS related to SARS-CoV-2 (29). Activation of angiotensin II receptors (AT2R) can be a mechanism that leads to vasodilation, apoptosis, and inhibition of fibroblast cell proliferation in the lung. Therefore, redirection of the RAS system to activate AT2R requires the use of the $C 21$ molecule as the selective and specific agonist of ATII R.

As mentioned above, stimulating the AT2 receptor by C21 can prevent and attenuate the progression of lung fibrosis, infiltration of macrophages in the lungs, lung inflammation, pulmonary collagen accumulation, and muscularization of the pulmonary vessels. C21 as a highly selective non-peptide agonist of $\mathrm{AT}_{2} \mathrm{Rs}(38-41)$ has an oral bioavailability of $20 \%$ to $30 \%$ and an estimated half-life of 4 hours in plasma (42). Administration of C21 in various cardiovascular disease models, including the postmyocardial infarction Wistar rat, the stroke-prone hypertensive rat, and the 2-kidney, and 1-clip hypertensive Sprague-Dawley (SD) rat (43-46), resulted in beneficial organ-protective effects. Also, Menk et al reported Direct AT2 receptor stimulation with $\mathrm{C} 21$ led to significant inhibition of tumor necrosis factor-alpha and IL-6 expressions in the lungs; and a rodent model of acute lung injury and stimulation of the AT2 receptor with the direct agonist Compound 21 (C21) might have a beneficial effect on pulmonary inflammation and might improve pulmonary gas exchange (12). Rathinasabapathy et al reported C21 treatment improved pulmonary pressure, reduced muscularization of the pulmonary vessels, and normalized cardiac function in male Sprague Dawley rats with induced lung fibrosis (24). However, a potential antihypertensive effect of C21 manifests itself invivo when the RAS pathway redirected to activation of AT2R because in physiological status, AT1R is predominant. Thus, to observe the effects resulting from AT2R stimulation, it may be necessary to block AT1R when combined with a low-dose ARB that does not modify the normal blood pressure; C21 exerts an antihypertensive action (47). Also, the ACE inhibitors mediate decreasing the conversion of ANGI to ANGII. An experimental model of acute lung injury (ALI) has proved that captopril can reduce pulmonary injury by protecting the vascular endothelium (33). Many ACE inhibitors are applied to treating hypertension and cardiovascular diseases. In this group of drugs, Captopril, Lisinopril, Enalapril, Ramipril, Perindopril, Benazepril, and Moexipril are known. Although the target of these drugs is ACE, due to the high similarity between the protein and structural sequences of $\mathrm{ACE}$ and $\mathrm{ACE} 2$, these drugs can affect both pathways (ACE and ACE2) (51).

The effect area of the proposed drugs on the RAS pathway is shown in the Figure $4 \mathrm{C}$.

The SARS-CoV-2 virus particles interact strongly with ACE2 through its S protein for its entry into the host cell (48). Therefore, antibodies and small molecular inhibitors that can block the interaction between ACE2 with recep- tor-binding domain (RBD) of SARS-CoV-2 $\mathrm{S}$ protein should be considered as the main part of the treatment (49). There is also a potential strategy to prevent ACE2 binding to SARS-CoV-2, which is a recombinant human ACE2 (rhACE2) as a competitive receptor for chelating the SARS-CoV-2virus particles $(31,32)$. The use of Ang II receptor blockers or ACE inhibitors has been effective in decreasing lung injury in animal models, but it might lead to systemic hypotension as a potential side effect. Since ACE2 protects the lungs from developing ARDS through dominating the AT2R in comparing with AT1R and redirecting the RAS pathway to promote the vasodilation and apoptosis for the severe acute respiratory syndrome (50), the recombinant ACE2 protein may have an important role in protecting ARDS as a mimicry Coronavirus receptor and also as a potential therapeutic approach in the management of emerging lung diseases $(25,26)$

According to the pathway blocked by ACEIs, in which angiotensin II is reduced, it is preferred not to apply this group of drugs, because angiotensin II should be available in the system for producing Angiotensin 1-7. The competition with the binding of SARS-CoV-2 with rhACE2 seems to effectively prevent its entrance into the host cell with chelating viral particles.

\section{Conclusion}

According to the mechanism of action and the signaling pathway of Coronavirus which affects the ReninAngiotensin system, we suggest the combination of C21 and ARBs as an applicable effective therapeutic protocol as well as rhACE2 as a preventing competitive molecule, which ablates the adhesion of the SARS-CoV-2 and may be an effective additional modality for the current therapeutic protocol, having all other medical considerations based on individual requirements.

\section{Conflict of Interests}

The authors declare that they have no competing interests.

\section{References}

1. Kin N, Miszczak F, Lin W, Gouilh MA, Vabret AJV. Genomic analysis of 15 human coronaviruses OC43 (HCoV-OC43s) circulating in France from 2001 to 2013 reveals a high intra-specific diversity with new recombinant genotypes. Viruses. 2015;7(5):2358-77.

2. Peeri NC, Shrestha N, Rahman MS, Zaki R, Tan Z, Bibi S, et al. The SARS, MERS and novel coronavirus (COVID-19) epidemics, the newest and biggest global health threats: what lessons have we learned? Int J Epidemiol. 2020.

3. Zu ZY, Jiang MD, Xu PP, Chen W, Ni QQ, Lu GM, et al. Coronavirus Disease 2019 (COVID-19): A Perspective from China. Radiology. 2020:200490.

4. Weiss SR, Navas-Martin S. Coronavirus pathogenesis and the emerging pathogen severe acute respiratory syndrome coronavirus. Microbiol Mol Biol Rev. 2005;69(4):635-64.

5. Huang C, Wang Y, Li X, Ren L, Zhao J, Hu Y, et al. Clinical features of patients infected with 2019 novel coronavirus in Wuhan, China Lancet. 2020;395(10223):497-506.

6. The Lancet. Emerging understandings of 2019-nCoV. Lancet. 2020;395(10221):311.

7. Mackay IM, Arden KE. MERS coronavirus: diagnostics, epidemiology and transmission. Virol J. 2015;12(1):222

8. Donnelly CA, Ghani AC, Leung GM, Hedley AJ, Fraser C, Riley S, et al. Epidemiological determinants of spread of causal agent of severe 
acute respiratory syndrome in Hong Kong. Lancet. 2003;361(9371):1761-6.

9. Lau SK, Woo PC, Yip CC, Tse H, Tsoi H-w, Cheng VC, et al. Coronavirus HKU1 and other coronavirus infections in Hong Kong. J Clin Microbiol. 2006;44(6):2063-71.

10. Guan WJ, Ni ZY, Hu Y, Liang WH, Ou CQ, He JX, et al. Clinical characteristics of 2019 novel coronavirus infection in China. N Engl J Med. 2020.

11. Carlos WG, Dela Cruz CS, Cao B, Pasnick S, Jamil S. Novel Wuhan (2019-nCoV) Coronavirus. Am J Respir Crit Care Med. 2020;201(4):P7-P8.

12. Wang D, Hu B, Hu C, Zhu F, Liu X, Zhang J, et al. Clinical characteristics of 138 hospitalized patients with 2019 novel coronavirus-infected pneumonia in Wuhan, China. JAMA. 2020.

13. Chen N, Zhou M, Dong X, Qu J, Gong F, Han Y, et al. Epidemiological and clinical characteristics of 99 cases of 2019 novel coronavirus pneumonia in Wuhan, China: a descriptive study. Lancet. 2020;395(10223):507-13.

14. Su S, Wong G, Shi W, Liu J, Lai AC, Zhou J, et al. Epidemiology, genetic recombination, and pathogenesis of coronaviruses. Trends Microbiol. 2016;24(6):490-502.

15. Ng MY, Lee EY, Yang J, Yang F, Li X, Wang H, et al. Imaging profile of the COVID-19 infection: radiologic findings and literature review. Radiol Cardiothorac Imag. 2020;2(1):e200034.

16. Xu B, Xing Y, Peng J, Zheng Z, Tang W, Sun Y, et al. Chest CT for detecting COVID-19: a systematic review and meta-analysis of diagnostic accuracy. Eur Radiol. 2020.

17. Udugama B, Kadhiresan P, Kozlowski HN, Malekjahani A, Osborne M, Li VYC, et al. Diagnosing COVID-19: The Disease and Tools for Detection. ACS Nano. 2020;14(4):3822-35.

18. WHO. https://www.who.int/emergencies/diseases/novel-coronavirus2019/events-as-they-happen. 2020.

19. Worldometer C. https://www.worldometers.info/coronavirus/. March $10,2020$.

20. https://www.worldometers.info/coronavirus. 2020.

21. Organization WHO. WHO Director-General's opening remarks at the media briefing on COVID-19- 3 March 2020.

22. Kumar S, Stecher G, Tamura K. MEGA7: Molecular Evolutionary Genetics Analysis Version 7.0 for Bigger Datasets. Mol Biol Evol. 2016;33(7):1870-4.

23. Tamura K, Nei M. Estimation of the number of nucleotide substitutions in the control region of mitochondrial DNA in humans and chimpanzees. Mol Biol Evol. 1993;10(3):512-26.

24. Rathinasabapathy A, Horowitz A, Horton K, Kumar A, Gladson S, Unger T, et al. The Selective Angiotensin II Type 2 Receptor Agonist, Compound 21, Attenuates the Progression of Lung Fibrosis and Pulmonary Hypertension in an Experimental Model of BleomycinInduced Lung Injury. Front Physiol. 2018;9:180.

25. Zou Z, Yan Y, Shu Y, Gao R, Sun Y, Li X, et al. Angiotensinconverting enzyme 2 protects from lethal avian influenza A H5N1 infections. Nat Commun. 2014;5:3594.

26. Zhang H, Baker A. Recombinant human ACE2: acing out angiotensin II in ARDS therapy. Crit Care. 2017;21(1):305.

27. Ruthman CA, Festic EJTaird. Emerging therapies for the prevention of acute respiratory distress syndrome. Ther Adv Respir Dis. 2015;9(4):173-87.

28. Phua J, Badia JR, Adhikari NK, Friedrich JO, Fowler RA, Singh JM, et al. Has mortality from acute respiratory distress syndrome decreased over time? A systematic review. Am J Respir Crit Care Med. 2009;179(3):220-7.

29. Kuba K, Imai Y, Penninger JM. Angiotensin-converting enzyme 2 in lung diseases. Curr Opin Pharmacol. 2006;6(3):271-6.

30. Peiris JS, Yuen KY, Osterhaus AD, Stöhr K. The severe acute respiratory syndrome. Nat Med. 2003;349(25):2431-41.

31. Ferrario CM, Schiavone MT. The renin-angiotensin system: importance in physiology and pathology. Cleve Clin $\mathrm{J}$ Med. 1990;15(Suppl 3):S1-S5.

32. Donoghue M, Hsieh F, Baronas E, Godbout K, Gosselin M, Stagliano N, et al. A novel angiotensin-converting enzyme-related carboxypeptidase (ACE2) converts angiotensin I to angiotensin 1-9. Circ Res. 2000;87(5):e1-e9.

33. Zambelli V, Grassi A, Bellani G. Role of the Renin-angiotensin System in ARDS. Annual Update in Intensive Care and Emergency Medicine 2012: Springer; 2012. p. 171-81.

34. Song L, Wang D, Cui X, Shi Z, Yang H. Kinetic alterations of
angiotensin-II and nitric oxide in radiation pulmonary fibrosis J Environ Pathol Toxicol Oncol. 1998;17(2):141-50.

35. Wei J, Xu H, Xiong J, Shen Q, Fan B, Ye C, et al, 2019 Novel Coronavirus (COVID-19) Pneumonia: Serial Computed Tomography Findings. Korean J Radiol. 2020.

36. Kuba K, Imai Y, Rao S, Gao H, Guo F, Guan B, et al. A crucial role of angiotensin converting enzyme 2 (ACE2) in SARS coronavirusinduced lung injury. Nat Med. 2005;11(8):875-9.

37. Gurwitz D. Angiotensin receptor blockers as tentative SARS-CoV-2 therapeutics. Drug Dev Res. 2020.

38. Carey RM. Update on angiotensin AT2 receptors. Curr Opin Nephrol Hypertens. 2017;26(2):91-6.

39. Padia SH, Carey RM. AT2 receptors: beneficial counter-regulatory role in cardiovascular and renal function. Pflugers Arch. 2013;465(1):99-110.

40. Chow BS, Koulis C, Krishnaswamy P, Steckelings UM, Unger T, Cooper ME, et al. The angiotensin II type 2 receptor agonist Compound 21 is protective in experimental diabetes-associated atherosclerosis. Diabetologia. 2016;59(8):1778-90.

41. Steckelings UM, Larhed M, Hallberg A, Widdop RE, Jones ES, Wallinder C, et al. Non-peptide AT2-receptor agonists. Curr Opin Pharmacol. 2011;11(2):187-92.

42. Wan Y, Wallinder C, Plouffe B, Beaudry H, Mahalingam A, Wu X, et al. Design, synthesis, and biological evaluation of the first selective nonpeptide AT2 receptor agonist. J Med Chem. 2004;47(24):5995 6008

43. Kaschina E, Grzesiak A, Li J, Foryst-Ludwig A, Timm M, Rompe F, et al. Angiotensin II type 2 receptor stimulation: a novel option of therapeutic interference with the renin-angiotensin system in myocardial infarction? Circulation. 2008;118(24):2523-32.

44. Gelosa P, Pignieri A, Fändriks L, De Gasparo M, Hallberg A, Banfi $\mathrm{C}$, et al. Stimulation of AT2 receptor exerts beneficial effects in strokeprone rats: focus on renal damage. J Hypertens. 2009;27(12):2444-51.

45. Rehman A, Leibowitz A, Yamamoto N, Rautureau Y, Paradis P, Schiffrin EL. Angiotensin type 2 receptor agonist compound 21 reduces vascular injury and myocardial fibrosis in stroke-prone spontaneously hypertensive rats. Hypertension. 2012;59(2):291-9.

46. Matavelli LC, Huang J, Siragy HM. Angiotensin AT2 receptor stimulation inhibits early renal inflammation in renovascular hypertension. Hypertension. 2011;57(2):308-13.

47. Foulquier S, Steckelings UM, Unger T. Impact of the AT(2) receptor agonist $\mathrm{C} 21$ on blood pressure and beyond. Curr Hypertens Rep. 2012;14(5):403-9.

48. Hoffmann M, Kleine-Weber H, Schroeder S, Krüger N, Herrler T, Erichsen S, et al. SARS-CoV-2 Cell Entry Depends on ACE2 and TMPRSS2 and Is Blocked by a Clinically Proven Protease Inhibitor. Cell. 2020

49. Chen Y, Guo Y, Pan Y, Zhao ZJ. Structure analysis of the receptor binding of 2019-nCoV. Biochem. Biophys. Res. Commun. 2020.

50. Kuba K, Imai Y, Rao S, Gao H, Guo F, Guan B, et al. A crucial role of angiotensin converting enzyme 2 (ACE2) in SARS coronavirusinduced lung injury. Nat Med. 2005;11(8):875-9.

51. Guy JL, Jackson RM, Acharya KR, Sturrock ED, Hooper NM, Turner AJ. Angiotensin-converting enzyme-2 (ACE2): comparative modeling of the active site, specificity requirements, and chloride dependence. Biochemistry. 2003;42(45):13185-13192.

52. Huang X, Dong W, Milewska A, Golda A, Qi Y, Zhu QK, et al. HCoV-HKU1 Spike protein uses O-acetylated sialic acid as an attachment receptor determinant and employs HE protein as a receptor-destroying enzyme. J Virol. 2015.

53. Gaunt ER, Hardie A, Claas EC, Simmonds P, Templeton KEJJocm. Epidemiology and clinical presentations of the four human coronaviruses 229E, HKU1, NL63, and OC43 detected over 3 years using a novel multiplex real-time PCR method. J Clin Microbiol. 2010;48(8):2940-7.

54. Su S, Wong G, Shi W, Liu J, Lai AC, Zhou J, et al. Epidemiology, genetic recombination, and pathogenesis of coronaviruses. Trends Microbiol. 2016;24(6):490-502

55. Wu K, Li W, Peng G, Li F. Crystal structure of NL63 respiratory coronavirus receptor-binding domain complexed with its human receptor. Proc Natl Acad Sci USA. 2009;106(47):19970-4.

56. Vlasak R, Luytjes W, Spaan W, Palese P. Human and bovine coronaviruses recognize sialic acid-containing receptors similar to those of influenza $C$ viruses. Proc Natl Acad Sci U S A. 1988;85(12):4526-9. 
57. Chen Y, Liu Q, Guo D. Emerging coronaviruses: genome structure, replication, and pathogenesis. J Med Virol. 2020.

58. Decaro N, Mari V, Desario C, Campolo M, Elia G, Martella V, et al. Severe outbreak of bovine coronavirus infection in dairy cattle during the warmer season. Vet Microbiol. 2008;126(1-3):30-9.

59. Wang D, Hu B, Hu C, Zhu F, Liu X, Zhang J, et al. Clinical characteristics of 138 hospitalized patients with 2019 novel coronavirus-infected pneumonia in Wuhan, China. JAMA. 2020.

60. Yeager CL, Ashmun RA, Williams RK, Cardellichio CB, Shapiro LH, Look AT, et al. Human aminopeptidase $\mathrm{N}$ is a receptor for human coronavirus 229E. Nature. 1992;357(6377):420-2.

61. Collins A. HLA class I antigen serves as a receptor for human coronavirus OC43. Immunol Invest. 1993;22(2):95-103.

62. Leung TF, Li CY, Lam WY, Wong GW, Cheuk E, Ip M, et al. Epidemiology and clinical presentations of human coronavirus NL63 infections in hong kong children. J Clin Microbiol. 2009;47(11):348692.

63. Patrick DM, Petric M, Skowronski DM, Guasparini R, Booth TF, Krajden M, et al. An Outbreak of Human Coronavirus OC43 Infection and Serological Cross-reactivity with SARS Coronavirus. Can J Infect Dis Med Microbiol. 2006;17(6):330-6.

64. Winter C, Schwegmann-Weßels C, Cavanagh D, Neumann U, Herrler GJJogv. Sialic acid is a receptor determinant for infection of cells by avian Infectious bronchitis virus. J Gen Virol. 2006;87(5):1209-16.

65. Ignjatovic J, Sapats S. Avian infectious bronchitis virus. Rev Sci Tech. 2000;19(2):493-501.

66. Bleibtreu A, Bertine M, Bertin C, Houhou-Fidouh N, Visseaux BJMemi. Focus on Middle East respiratory syndrome coronavirus (MERS-CoV). Med Mal Infect. 2019.

67. Gao QY, Chen YX, Fang J. 2019 novel coronavirus infection and gastrointestinal tract. J Dig Dis. 2020.

68. Organization WH. WHO Director-General's opening remarks at the media briefing on COVID-19 - 3 March 2020

69. Li W, Moore MJ, Vasilieva N, Sui J, Wong SK, Berne MA, et al. Angiotensin-converting enzyme 2 is a functional receptor for the SARS coronavirus. Nature. 2003;426(6965):450-4.

70. Ströher U, DiCaro A, Li Y, Strong JE, Aoki F, Plummer F, et al. Severe acute respiratory syndrome-related coronavirus is inhibited by interferon- $\alpha$. J Infect Dis. 2004;189(7):1164-7.

71. Wege H, Ter Meulen V. The biology and pathogenesis of coronaviruses. Current topics in microbiology and immunology: Springer; 1982. p. 165-200. 